\title{
Church, mission and reconstruction: Being a church with integrity in reconstruction discourse in post-colonial Zimbabwe
}

\begin{tabular}{|c|c|}
\hline \multicolumn{2}{|c|}{$\begin{array}{l}\text { Authors: } \\
\text { Canon B. Shambare } \\
\text { Selaelo T. Kgatla }\end{array}$} \\
\hline \multicolumn{2}{|c|}{$\begin{array}{l}\text { Affiliations: } \\
\text { 'Department of Science, } \\
\text { Religion and Missiology, } \\
\text { Faculty of Theology, } \\
\text { University of Pretoria, } \\
\text { South Africa }\end{array}$} \\
\hline \multicolumn{2}{|c|}{$\begin{array}{l}\text { Research Project Registration: } \\
\text { Project Leader: S.T. Kgatla } \\
\text { Project Number: } 04486863\end{array}$} \\
\hline \multicolumn{2}{|c|}{$\begin{array}{l}\text { Description: } \\
\text { Dr Shambare is participating } \\
\text { in the research project, 'The } \\
\text { role of German Churches in } \\
\text { the demise of apartheid in } \\
\text { South Africa', directed by Prof. } \\
\text { Dr Thias Kgatla, Department } \\
\text { of Science of Religion and } \\
\text { Missiology, Faculty of } \\
\text { Theology and Religion, } \\
\text { University of Pretoria. }\end{array}$} \\
\hline \multicolumn{2}{|c|}{$\begin{array}{l}\text { Corresponding author: } \\
\text { Selaelo Kgatla, } \\
\text { kgatla@mweb.co.za }\end{array}$} \\
\hline \multicolumn{2}{|c|}{$\begin{array}{l}\text { Dates: } \\
\text { Received: } 09 \text { June } 2017 \\
\text { Accepted: } 17 \text { Nov. } 2017 \\
\text { Published: } 24 \text { May } 2018\end{array}$} \\
\hline \multicolumn{2}{|c|}{$\begin{array}{l}\text { How to cite this article: } \\
\text { Shambare, C.B. \& Kgatla, S.T } \\
2018, \text { 'Church, mission and } \\
\text { reconstruction: Being a } \\
\text { church with integrity in } \\
\text { reconstruction discourse in } \\
\text { post-colonial Zimbabwe', } \\
\text { HTS Teologiese Studies/ } \\
\text { Theological Studies 74(1), } \\
\text { 4698. https://doi.org/ } \\
\text { 10.4102/hts.v74i1.4698 }\end{array}$} \\
\hline \multicolumn{2}{|c|}{$\begin{array}{l}\text { Copyright: } \\
\text { (C) 2018. The Authors. } \\
\text { Licensee: AOSIS. This work } \\
\text { is licensed under the } \\
\text { Creative Commons } \\
\text { Attribution License. }\end{array}$} \\
\hline \multicolumn{2}{|l|}{ Read online: } \\
\hline 口ffin & $\begin{array}{l}\text { Scan this QR } \\
\text { code with your } \\
\text { smart phone or } \\
\text { mobile device } \\
\text { to read online. }\end{array}$ \\
\hline
\end{tabular}

\begin{abstract}
The church in Africa, like its counterparts elsewhere in the world, is called to fulfil the mission of God as expressed in the call 'Missio Dei' and influentially remains with the integrity of the mission of Christ (Missio Christos), which is liberative and practical. For Christ was not only concerned with the spiritual needs of the people, but also with their material well-being. The following question therefore arises: how can the church in Africa, in general, and in Zimbabwe, in particular, actively do God's mission and remain with integrity in the midst of the reality of suffering. Furthermore, how can the church for mission and reconstruction be understood in a post-colonial Zimbabwe given the contextual realities of political crises, corruption, poverty, moral decadence, defined or censored truth, leadership crises and no freedom of expression? This article argues that, although the church is faced with these arduous realities, it remains called by God to do God's mission. While in post-colonial Zimbabwe the socio-political, socioeconomic and socio-religious situation might seem hopeless, the church has remained vibrant and alive for reconstruction theology. The transformation of society is possible given the authority and mission mandate of the church. This article argues that the church is a key player in reconstruction theology and in the transformation of society. For transformation to be possible, the church should witness to the gospel of Christ without fear of being labelled, castrated and persecuted. The article asserts that the spirit of the Bible should be revived in a time of reconstruction in Zimbabwe. The assumption in this article is that Zimbabwe is ready for reconstruction discourse. For this to happen, the researchers argue that the church as a critical relevant player in reconstruction needs to 'be church' in its missional mandates. Integrity is essential if a church wants to be relevantly missional and reconstructive. Integrity means that the church has to embrace the risks and opportunities associated with mission.
\end{abstract}

\section{Introduction}

Missiologists such as Raja et al. (2010:5) argue that reconstruction 'is the rebuilding of society to a new-better level in cooperation with God's redemptive work and transformative love'. Thus, reconstruction theology becomes an expression of emancipation and transformation (Maposa, Sibanda \& Makahamadze 2011:249). Reconstruction theology in this form seeks to respond to the renewal and transformation of communities. Hence, Villa-Vicencio (1992:14) states that reconstruction theology is a prophetic theology dealing with and responding to contemporary challenges and issues. It is a kairos theology, for kairos moments. Therefore, in Zimbabwe, as in most post-colonial African countries, reconstruction is an ideal long walk to transformation. While the attainment of it seems a nightmare, as can be seen from the absence of and pretensions to it, the walk is worth taking. In Zimbabwe itself, the road to reconstruction since independence from colonial oppression has been filled with blind alleys and impasses.

Throughout history, the church has been a recognised key partner with the state, in particular, and society, in general, in the discourses facilitating transformation and democratisation of any given society (Banana 1991; De Gruchy 2002:5). It is in this view that the church shares in the mission of God and Christ as a pacesetter in offering prophetic advocacy, reconstructing confidence, transforming advocacy and rebuilding a mobilisation spirit.

In this article, the missiological perspective to reconstruction is outlined and explored in relationship to the church's role in the reconstruction of society. The article addresses several questions such as: what is Christian mission?, how is Christian integrity worthy to influence

Note: This article represents re-worked aspects from the doctoral research of Dr Shambare, conducted under the supervision of Prof. Dr Thias Kgatla, Faculty of Theology and Religion, University of Pretoria. It was presented as a paper at the Anglican Diocese of Harare Clergy Theological Academy on $07-12$ August 2016, Harare, Zimbabwe. 
transformation in society? and what is the role of the church in mission and reconstruction? It explores the foundation of mission, the authority of the church in mission and the models of the church in reconstruction. For despite different perspectives, the thrust of reconstruction theology has been to challenge the contemporary Christian churches to work towards and to participate fully in the transformative building of better and just societies.

Moreover, the article further interrogates Jesse Mugambi's (1995:5) challenge to African theologians and church leaders to critically engage with the following questions: how can the Christian church in post-colonial Africa help Africans to grow out of the vicious cycles of poverty and untold suffering?; how can mission remain 'business-as-usual' (Maluleke 2003:63) when millions in Zimbabwe are suffering, dying, having their democratic rights denied and seeing the manifestation of emperors and pharaohs? In so doing, the article addresses the aspects of what the content and context of mission is in Zimbabwe, how the church in Zimbabwe can embody the integrity of mission and what challenges the church in post-colonial Zimbabwe faces and what models of church best suit the context of mission.

\section{Meaning of integrity: Missional perspective}

The word integrity is taken from the Latin word integritas and integer, which can be taken to denote being entire, whole or in the original state. According to Roget's International Thesaurus (2010), the English term 'integrity' refers to artlessness, probity, wholeness, completeness, simplicity, particularity and soundness. Hunter (1990:397) argues that 'integrity is the state of wholeness and completeness which the process of life of faith is always striving to bring into being'. In this article, the focus is not so much on the ethical and moral behaviour as it might appear, but on the 'church being church' (Nel 2010) in reconstruction theology in postcolonial Zimbabwe. In other words, it is about the church being whole and being particular in missio Dei (Dreyer 2016:2) so as to influence reconstruction. The integrity of the church is witnessed when the church is able to be a church in the time and context of its existence regardless of the threats circumstances can present. The fundamental essentials, the character and being of the church, have to manifest in its defined mission and missiological enterprises to transform reality in any given history. The church has to exhibit the preparedness to become visible and to problematise the realities of its times in light of God's loving transforming salvation. The church, with integrity, searches for and defines itself as inadequate in itself but adequate with Christ and with the Holy Spirit that enables it to read the signs of the time and strengthens its discernment to take corrective action.

The integrity of the church is visible when it insists on the imprescriptible right to intervene in temporal matters (Lamont 1959). Therefore, this article seeks to analyse the mission nature and task of the church in post-colonial Zimbabwe.

\section{The perception of mission: Missiological reconstruction outlook}

The meaning, context and dimension of mission have been the subject of investigation and debate among missiologists, mission practitioners and theologians. Orville Jenkins (1984:4) notes that the concept of mission has undergone considerable paradigm shifts over the centuries. This has also been attested by (Bosch 1991:2; Verkuyl 1978), saying that 'the Christian mission at least as it has traditionally been interpreted and performed has transformed not only outside itself but also from within its own ranks'. The traditional concept of mission and missionary is enshrined in the sending of preachers to distant places. Christian mission has evolved to be understood as the:

Activity of the church which in its enterprise of faith seeks to transform reality. Mission can no longer only be descriptive of the business of the church; rather, it is an enterprise and participation in God's transforming love. (Bosch 1991:xv)

David Bosch (1991:xv) further articulates that mission is that indispensable dimension of the Christian church that purposes to transform reality around society and it is continuous. Moreover, Jesse Mugambi (1995:240) says that 'mission is part of the definition of the church'.

The church by its nature is unavoidably missionary. Accordingly, Philemon Mwaura (2010:4) describes mission as that 'frontier of the Christian church based on belief, conviction and commitment to cooperate in God's redemptive purpose and to promote the values of the Kingdom'. Evidently, mission is the divine fundamental obligation of the Christian church to influence the wellness of community based on the principles of the gospel. David Bosch (1991) (1991) emphasises that:

Mission, in this perspective, becomes that dimension of the Christian faith that refuses to accept a bad reality as it is and aims at transforming the bad state into a good state. (p. xv)

Furthermore, Christian mission 'denotes the total task God has set for the church for the salvation of the world, but also relates to specific contexts of evil, despair and lostness' (Bosch 1991:411). The chief end of mission is that God may be glorified, first among a people enjoying wholeness in a given community and then through them in every aspect and area of their lives.

The harmony in missiology and mission perspective begins with God, who works primarily through the church to reach and to transform the world. Mission, which is also constantly referred to as intentional priority evangelisation (Engen 2006:80), is understood as an 'encounter of people with the Good News of God's transforming love' (Mwaura 2010:5) as proclaimed by and through Jesus Christ (Mt 22:34-40; Jn 15:9-17). David Bosch (1991) dedicates a section in his book 
entailed Mission as Evangelism (Bosch 1991:409-420). He traces the relationship between mission, evangelism and evangelisation. He admits to the existence of controversies in trying to understand mission in terms of evangelism. For the scope and range of mission constitutes evangelism (Bosch 1991:409, 418). Bosch argues that 'mission and evangelism are not synonymous but they are indissolubly linked together and inextricably interwoven in theology and praxis. Yet mission is wider than evangelism' (Bosch 1991:411). The context of evangelisation is based on the notion of salvation that implies liberation from all that oppresses and dehumanises people: social, cultural, economic, political, religious or personal (Mwaura 2010:5). Evangelism and mission both target to enlist people to the transforming love of God, the reign of God and the liberation of God. Intentional priority evangelism draws the fraternity of the church and individual believers to the value of responsible living. Living out the gospel is accepting to live with brothers, with all of them, not only with the holy and pure, faithful and healthy, but also with the lame and the crippled, the suffering and the poor. Moreover, it involves bearing witness to God's infinite patience and love, inexhaustible forgiveness and constantly renewing grace (Motte 1992:453).

This means that authentic Christian social action has to be accompanied with the proclamation of the gospel (intentional evangelism). Therefore, Jurgen Moltmann (1977) asserts that:

evangelisation is mission but mission is not merely evangelisation, mission is broader and embraces all activities that serve to liberate people from slavery in the presence of the coming God, slavery which extends from economic necessity to God forsakenness. (p. 10)

Mission and evangelism in this way will be rooted in the gospel of Christ of the good news of the Kingdom of God (Mk 1:15) and the declaration of the year of God's favour (Lk 4:19). Jesse Mugambi (1995) argues:

\begin{abstract}
It is quite clear that Jesus, in his public ministry was actively and simultaneously involved in both personal and social reconstruction. Jesus mobilised his followers to become involved in social change having convinced them of the necessity and urgency to change their attitudes towards themselves and the world. (p. 6)
\end{abstract}

The biblical traditions have enabled the church to be authoritative in addressing or pointing out the social imbalances, decadences and the lack of human value. The biblical perspectives clearly demonstrate that the Christian church possesses a great obligation to proclaim liberty, peace and justice for the good of God's creation (Bosch 1991:412; Kirk 1999:19).

Mission in the post-colonial context seeks to make significant contributions to the renewed dignity of human beings in light of the Kingdom of God rubrics. Then, John Pobee (1990) understands mission as:

Enabling people to do the will of God, working for a community of communities, bringing wholeness and healing ... The key words are enabling not only by the word of mouth 'in pulpit pronouncements' but also in life style and in commitment; seeking community out of a plurality of peoples, cultures, religions, gender and ages. Seeking wholeness and healing in a world that is 'out of joint' a world in which human inhumanity to one another is an everyday occurrence, a world in which people live in constant fear, no real truth, hopelessness, cynicism, and scepticism, violence, bad governance baptised as good, and poverty as the daily bread. (p. 55)

The Zimbabwean context requires healing and reconstruction for wholeness of life to be realised. Mission theology subscribes to the emphasis that Christianity and Christians have the responsibility to raise questions that are most relevant to human well-being and societal wholeness. This responsibility will be guided and premised on the principles of the gospel of God.

Mission is based on some founded formative sources and this section outlines some foundations of mission from which the church draws inspiration in undertaking and participating in God's transforming love. These include experience, scripture and theology.

\section{The experiential factor of mission: Reconstruction from realities}

Christian mission is not only the project of expanding churches, but also of the church embodying God's presence in the world. This entails that God's mission is realitycentred. Mission does not exist or happen in and from a vacuum (Balia \& Kim 2010:12), but it is grounded in and derived from a particular context and addresses particular challenges and concerns. The reception of the gospel of Christ is embedded in specific human history and experience (Banana 1991:1). The experience of the context of mission forms a solid foundation for reconstruction discourse. The experiences of post-colonial Zimbabwe become an informative factor of doing reconstruction mission. Mission has the intertwined obligation of being informed by the experience of both past and present and in seeking to impact and to influence humans with an experience to move forwards with vision.

Mission founded on experience is polyvalent and it brings not only the methodological critique to mission, but also the integrity obligation of the church. It helps to interrogate the exclusionary nature of the former mission practices that neglect 'experiences', in general, and affirm certain 'experiences', in particular (Balia \& Kim 2010:13). Mission founded on experience with its 'orthopathic' dimension will then infuse the oppressed, the suffering and the community in decay (Hiebert 2006:209). In other words, mission infuses the strength to rise above the debris of destruction, the debris of dehumanisation and the debris of decadence and seeks reconstruction and transformation of their condition (Samuel 1998:62). When this consciousness becomes a hermeneutical premise, people are empowered to 'risk questioning, to have the courage as displayed by Nehemiah, in facing the Emperors with a reconstruction conscience' (Poggo 2013:30; 
Samuel 1998:145). Then, the community will be able to reinterpret the Nehemiah scripture in light of their experience and the insights of reconstruction theology.

Therefore, attentiveness to experiences of those who are affected in post-colonial Zimbabwe is relevant for reconstruction discourse to be transformative. The experiential foundation of mission also seeks to explore the historical dynamics of power, politics and changing relationships at every stage and situation of history. The Christian church in mission is no longer at liberty to talk about Jesus in any way and from nowhere. Missiologically, 'the church is challenged to speak about Jesus from within the context of the community of believers, the whole people of God past and present' (Bosch 1991:22; Yonder 2014:19). The church is invited and sent out to listen, to wait, to serve and to be stewards of enhanced life through the pursuit of the justice, advocate, peace, reconstruction and well-being of humanity (Bishau 2013:70; Ilo 2016:17).

\section{The biblical foundation of mission: Reading the Bible for reconstruction}

The Bible inspires a given community to respond to God's initiatives of transformation and to respond to their conditions in enhancing life (Bosch 1980; 1991:15; Gathogo 2007). The reading of the Bible in different contexts has demonstrated the paradigms in biblical criticism, as changing contexts affect witness, understanding and engagement in God's mission. This has brought a realisation that the Biblical texts are 'polysemic', containing multiple layers of meaning useful for mission (Togarasei 2008:72). If Christian mission is to be meaningful, then the undertaking of biblical assessment is necessary in the form of missional exegesis of biblical texts. Marc Spindler (1995) provides that:

Mission today must be seen as arising from something fundamental, from the basic movement of God's people towards the world. The activity of living out the creation plan of God exhibited in Genesis 2 (Adam living in harmony with God and all creation), good news of salvation as preached and lived by Jesus Christ and the new creation in Paul's teachings. (p. 124)

The Bible is the authority for doing theology and as such it is the authority for mission. Mission undertakes that the Bible is a critical source of doing mission (Balia \& Kim 2010:23; Spindler 1995:125). The Great Commission (Mt 28:18-20) biblical text is one such significant motivating mission text, which has been used from both ends, including oppressive misinterpretations (Bosch 1991:15; Wright 2006:40). The New Testament is associated with mission. As Rzepkowski (1974:80) puts it 'the decisive value of the New Testament is mission. The New Testament is essentially a book about mission'. The incarnation of Jesus makes mission not only a possibility but also an obligation of the church. Incarnation establishes a paradigm for mediating God's redeeming presences in the broken society.
In the Old Testament, God is understood as a 'God who reveals himself; who among other characteristics has compassion on the poor, the oppressed, the suffering, the weak and the outcast' (Bosch 1980:50). For Ka Mana (1991), the Old Testament has a:

Keen interest in the founding crises of humanity. Reading the stories in Genesis for example, the Eden narratives (Genesis 3), Cain and Abel narratives, the Abrahamic narrative, Essau and Jacob narratives shows a crisis-ridden drama. (p. 56)

Missiologically, in these narratives, there are new horizons and renewed opportunities which God continually offers individuals and societies to become empowered with a new 'sense of responsibility and creativity in order to reconstruct new social structures for a better future' (Dedji 2001:258).

In Africa, the dynamic of the Exodus relevantly epitomises the activity of God who seeks liberation and justice. There, God makes himself missionary in drawing near to the enslaved humanity to redeem them (Ex 3:6-9). The essence of mission is firmly rooted in God who responds to the Israelite's cry for deliverance and justice. Therefore, the Israelites' dignity was restored by the intervention of God. This is the self-emptying of God for the liberation of humanity. David Bosch (1991) articulates that:

The Old Testament depicts a God who is present, a God who acts, a God of promises and a God who is involved with the realities of human existence. God's presence is clear in the hierophanic experiences of revelations. (p. 17)

In Zimbabwe, people are aware of God's presence in worship and prayer, healing and deliverance, but above all in his historical acts as recorded in the Old Testament of deliverance, restoration and reconstruction.

The re-reading of Ezra-Nehemiah in the Zimbabwean postcolonial context will show that there is need for the church to return to its mandate of advocating for reconstruction. To read the Bible as a missionary text and to see the Christian faith as a missionary faith in Africa supposes a compulsion to objectively scrutinise the challenges affecting people and mapping the solution from inspirational biblical texts. Missiologically, transformation is realised when the people in sufferance, poverty, dispossessed and struggle begin to read, pray and live out the active hope that is exhibited in the Nehemiah corps. Nehemiah's rallying outcry 'let's begin building' is a powerful symbol of pro-activity and hope amid full-scale human disaster' (Dedji 2001:258). Reading and locating the context and content for the people of Zimbabwe in light of the biblical text of Nehemiah is a mission endeavour and rapidly transformative in action. Taking Nehemiah (the leader of reconstruction) symbolically to represent a church in mission, it becomes evident that the church in Zimbabwe has been called and established to be a concerned church. The church's concern should trigger the desire to see transformation as possible regardless of the powers that be, 
the circumstances and the resources available. ${ }^{1}$ The church cannot afford to be indifferent to the situation of a postcolonial Zimbabwe.

\section{The theological foundation of mission: Reconstruction theology relevance}

A Christian theological formative factor of mission revolves around the understanding of theology, which is orthopraxis in outlook. Theology is a reflection on the ways in which God reveals self to humanity. Theology becomes the construction of God's action in the context of the believing community; it is an intentional reflection of the people of faith, their events and their stories. Furthermore, Macquarrie (1977) stipulates that:

Theology is a practical discipline that seeks to make the content of faith meaningful and understandable in a given context, using the thought forms and language available to the community of faith. (p. 6)

Theology aims at making faith intelligible and consistent with reality.

David Bosch (1991:22) provides that 'a theological foundation of mission is only possible with reference to the point of departure of faith: God's self-communication in Christ as the basis of mission reflection'. Christian mission is not mission without faith in God; it includes faith in Jesus Christ and the wholeness of life. Therefore, a Christian is a person who has accepted the Christian faith and made his or her decision to become a follower of Jesus Christ. Thus, the African Christian mission will be determined by those who experience 'the power of the gospel in transformation of their reality' (Mugambi 1989:11).

Authentic mission is therefore founded on the missio Dei, and more recently has found expression in missio en Deo (mission in God). Missio Dei and missio en Deo will be effective when founded on an encounter with God that leads to practical participation (Bosch 1991:391; Heaney 2015:153). This understanding of mission therefore defines the essential task of the church in terms of the representative of the gospel and 'the ambassador of Christ' (Balia \& Kim 2010:12; Raja et al. 2010:6). The church participates in the activities of God based on the Trinitarian understanding of creating, delivering and sustaining humanity (Raja \& Benjamin 2010:17). These activities are inclusive, open-ended and reconstructive. They include and go beyond charity, evangelism and the planting of churches. This led Canaan Banana (1980) to observe the following:

Theologically, the church has to re-assess the implications of the Christian message in a new social, political and economic

\footnotetext{
1.Zimbabwe gained political independence in 1980. At one moment, it was the bread basket of Africa, with a high literacy and employment rate; however, currently, it is basket of Africa, with a high literacy and employment rate; however, currently, it is
rated the begging basket of Africa, and its citizens are economic or political refugees rated the begging basket of Africa, and its citizens are economic or political refugees
in other parts of the world. There is a high rate of unemployment. Zimbabwe is yearning for social, economic and political reconstruction. The time to focus on the reconstruction mission is evident by the post-colonial era. The corps of EzraNehemiah brings inspiration to a hopeless nation (Bakare 2013:7; Hill 2005:2).
}

climate. Theology in my view, while finding its base from the Biblical text, must of necessity find expression within the context of the human situation. (p. 95)

The church is theologically challenged to missiologically influence the world to be a better place for all people to experience wholeness and the respect of each other's dignity. Therefore, reconstruction theology is relevant in Zimbabwe, because it is a praxis theology influenced by the human experience and involves deep reflections on the past, the present and a better future. Andrew Kirk (1999) proposes a theology of mission:

Whose task is to validate, to correct and to establish on better foundations, the motives and actions of those wanting to be part of the answer to the concerns of God and God's kingdom. (p. 21)

\section{Church: The answering player in Zimbabwe}

The church must become part of the answering team to the issues of reconstruction mission. The church is called to participate in the integral mission because of its position, power and location. Missiologically, the church's participation in mission and social transformation is derived from the Trinitarian God. ${ }^{2}$ The church's power and treasures are not in its structures or institutional privileges but rather the church's power is 'through the announcement of the cross and death of the Lord and through relying on the power of resurrection for strength and continuation in the missio Dei' (Ilo 2016:22). In exercising this power, the church will shape a new, transformed ecclesiological outlook that is centred on involvement and participation in the existential life. The socio-political and socio-economic commitment of the church is displayed in participating, denouncing and offering a sustainable option for the sake of the people's political and economic emancipation. Bienvenu Mayemba (2016) argues that:

The church should exemplify the qualities of Nehemiah (the reconstructor), Jeremiah (the prophet) and the Good Samaritan. It has to share and proclaim the joy of the gospel. It also has to challenge, question and denounce what it opposes. It should be involved socially by works of mercy and charity. (p. 53)

In this nature, participation is defined by loving experience and compassionate solidarity with the people in their context. The church is there to influence a transformed, just and conscious community. Bishop Kevin Dowling (2016) states that:

Our reality in Africa points to the need to positively revive and ground a reflection on the meaning of the church's social teaching. To ensure the common good of all citizens, the church [must] transform citizens into becoming and being active agents of transformation in their own communities by using their insights and experience to develop policies and practices that will make a real difference in their quality of life. (p. 7)

2.This participation can be seen in the history of salvation: the Triune God is the giver of life, creating and reconstructing the world. God's incarnation in the body of Jesus Christ participates in the vulnerability and suffering of humanity and creation, but overcomes suffering in the resurrection. The Holy Spirit of God is present since creation and is actively participating in the experiences of the people. 
The common good should be defined contextually. In Zimbabwe, the aspect of justice, distribution of resources and power, accessibility of social services, eradication of manmade poverty and the respect of humanity and creation are critical concerns during post-independence. The church should ensure and promote a social compact in which everyone in society participates in a spirit of responsibility, accountability, solidarity and collaboration to ensure that all citizens experience growth in their human dignity as human beings created in the imago Dei (Dowling 2016:8).

The church is invited to be the conscience of society. As a custodian of social conscience, the church has to point out and criticise the negligence of the common good. In Zimbabwe, the aftermath of political independence is befouled with bitter disappointments. Accordingly, Colette Coula (1997:220) states that in Africa many things are taken for granted, crimes go unnoticed because they have become commonplace and normal'. The church should address the conscience and attitude of society through teaching and preaching the undiluted gospel of Christ. Canaan Banana (1991) appreciates that the church is to be the conscience of the community in all the state of affairs of the community, including spiritual, political, social, moral, economic and cultural. Banana argues that, 'churches are responsible for being conscious of the struggles of the oppressed and the marginalised in their communities and contexts' (Banana 1991:1). In reconstruction discourse, the urgent task of the church is to 'influence the emergence of individual sustainable creativity, to encourage communities to move out of paralysing fear and help them develop critical understanding of their situations' (Ela 2005:52).

Banana suggests that the new vision for the church should aim at confronting and tackling the multilayered concerns of the people in post-colonial African. According to Banana, 'the church should adopt the militancy vision and be apolitical yet political' (Banana 1991:2). This militancy vision is missionary in that the church is biblically authorised to say 'no' to the world, as an expression of opposition to the dehumanising status and at the same time to say 'yes' as an expression of solidarity with society without losing the principles of transformation from Jesus Christ (Bosch 1991:11). Jesus Christ confronted the religious and political authorities of his social context and reshaped people's distorted understanding of power, law and greatness (honourable). He transposed these concepts with responsibility, humility and accountability. The church in reconstruction should foster Christian-driven power of active resistance to injustice and oppression and instil the messianic hope (Ela 2005:29). This militancy mission outlook of the church requires determination and commitment.

The church today is challenged to have a faith and mission that speaks and denounces all forms of human subjugation and human alienation. The church is called to uphold the prophetic mission guided with a prophetic vision. According to Elsa Tamez (2001), a:
Prophetic vision and dream is a response to a state of affairs with which a community in crisis will be deeply dissatisfied with its current status of existence and that it seeks transformation and change. (p. 59)

The church, in its mission, will stage the prophetic vision and dream of a better world, if it upholds and exhibits the authority as given by Jesus. Jesus prophetically 'challenged his Palestinian-Jewish culture, sought to evangelise it from within and mandated the church to speak prophetically with love' (Flemming 2005:23). Jesus, through prophetic teaching subverted prevailing attitudes towards wealth and riches (Mk 10:22-25). He transformed the dominant social norms by touching lepers, eating with the alienated, affirming the downtrodden and assuring the unnamed and women of their value to life. This is the prophetic reconstruction vision that encapsulates the life desired, not the life survived. It can be argued that from independence in 1980 to date, Zimbabwe has been a country in transition to reconstruction (Chimhanda 2009:105). This is so because from its emergence from colonial rule, Zimbabwe has a chequered history of repeated civil strife, economic scramble and political intolerance, emanating from selfish ambitions and ill-conceived bids to transform society.

The church is exposed to criticism from the politicians and other sectors that benefit from politically unchecked operations. It is exposed to the risk of accepting the mission regarding the politics of human life and survival. As for Karl Rahner, (1974:29-34), the church operates in an environment and situation marked by public and political consciousness to exclude and alienate. Christians in this environment must expect to be 'dirty' and be 'a little flock' (Rahner 1974:34) from the prevalent opinions and feelings of their social environment. While this is happening, the authority of the church, the magisterium, ${ }^{3}$ remains, but it must be more careful to show that its mission and teachings are rooted in the gospel. In all this, the church must be ready and take the risk as an essential component of mission. Karl Rahner encourages the church saying:

This risk is necessary; if the church is not to seem to be pedantic; living in a world of pure theory, remote from life, making pronouncements that do not touch the concreteness of real life. In the concrete set up of this complex world, with complicated politicians, the church should be able to discern when to say 'no' to political proposals and when to play the wait and see, for this is the compass piddle for the church to remain in the ground of mission. (Rahner 1974:98-100; Villa-Vicencio 1992:186)

Risking itself and remaining resolute to the truth of the gospel without the luxury of certainty is part of the mission reconstruction journey that the church is obliged and called to participate in.

\section{Propaganda De Tat: An integrity call}

The propaganda of deed means that the church must accept the responsibility to be an advocate of reconstruction. 3.The teaching authority of the church 
The nature of this responsibility requires the church to speak authoritatively and accountably to those who wield power and to those who have become only mere observers to the levels of decadence (Phiri \& Nadar 2010:92). David Bosch (1991:416) argues that people are not so much impressed by the miracles of itinerant evangelists, but rather 'when people look up to the church they are more concerned with the propaganda der tat - propaganda of the deed' (Bosch 1991:191). In this context, the church of deeds is a church that cares for the people's welfare.

The church has to apply itself to the present issues on the ground, with prophetic voice and action. The authority confided in the church makes the church powerful to speak with authority, the undiluted message of reconstruction, and it must never be silent in times struggle. The former Catholic Bishop of Umtali (Mutare) and the Rt Rev Donal Raymond Lamont (1959) wrote in a Pastoral Instruction (Letter) to the Christian believers entitled 'Purchased People' that the mission call of the church in times of struggle is as follows:

The church united under the leadership of Jesus, must teach, govern in the things spiritual and administer the patrimony of sanctification committed to them by the author of all sanctity himself. It would constitute the most dreadful apostasy when the church and its bishops fail in teaching and leaving out the mission entrusted to them, seeking to come to terms with the spirit of worldliness, taking secularism and materialism for granted and attempting co-existence with a Godless world. (Lamont 1959:4)

The church remains church and influential when the tide is swerving in the direction of struggle. Bishop Lamont (1959) went further to encourage:

the church to speak out the word that transforms, and affirms the dignity of the whole creation. No matter what the threats, what the opposition and what the criticism. It should remain prophetic. (p. 7)

The propaganda der tat mission empowers the church to speak the truth of the gospel because truth telling is critical for reconstruction to be possible. The church in this situation is challenged to create space for storytelling and it is through communal mutual storytelling that the community is exposed to the truth of the gospel, truth to love and truth to seek justice and mercy. In this way, the church will be able to prepare its members to be instruments of truth for the benefit of the community. Jose Chipenda (1997) argues that in the church of deeds:

God is its underwriter, it heals hurt lives, comforts old people, challenges youth and denounces all divisions and classifications. This church interprets the truth in terms of truth and inspires courage for this life and hope for the life to come. (p. 38)

\section{The church for reconstruction: Church with others, for others}

The 98th Former Archbishop of Canterbury, Archbishop William Temples (1942:56), asserts that a church in any given community should exist for the sake of the community's pressing matters. The church is the only institution that has to exist for the benefit of those who are not its members. Similarly, Dietrich Bonhoeffer argues that 'the church is church only when it exists for others...not dominating, but helping and serving' (Bonhoeffer 1967:112, 1974:127; Bosch 1991:375). The church in this outlook has to share in the secular problems of ordinary people in society. The church, as mandated by Christ, should be there for others not itself, because the church is the body of Christ; hence, it is 'church only when it exists for others' (Bethge 1972:75; Bonhoeffer 1974:127). In this perspective, to exist for others is to exist with content and in context with society's existential realities. This understanding provides the basis for a post-colonial Zimbabwean ecclesiology, vision and church location. In these instances, the church for others should focus on the reconstruction of the community.

During an interview with Bishop Ishmael Mukuwanda ${ }^{4}$ on 19 June 2014, he used the analogy of the hospital, doctor and sick patient to refer to the situation in Zimbabwe. Bishop Mukuwanda alluded that:

'the nation of Zimbabwe is in an intensive care unit, the nation is ill and the church should not only be like visitors to the sick bed, but as doctors on the sick patient.' (Interview on 19 June 2014, Gweru)

This is a challenge to the church, for doctors seek solutions to save the patient's life, while visitors only ask what the doctors have said concerning the patient's condition. The church for reconstruction not only has to do a diagnostic assessment but also has to strive to help the situation. The church for reconstruction has to actively be there for the struggling nation.

The church is being challenged to move away from theoretical pronouncements from the pulpits to active involvement in the real concerns of the community (Bosch 1991:416). The church's argument for reconstruction and transformation should not be an abstract argument but a reality-inspired one. Ultimately, the church has to develop a theology of meaning for all, which is based on the moral integrity and reality of the Christian faith. It is argued that while Christians pray '... thy Kingdom come and be established ...' (Mt 9), it is clear that the kingdom of God would not be fully realised in this complex and plural world (Chitando 2009:96).

The church for reconstruction is a missional church, prepared and aware of the consequences of its prophetic voice. The church would take total responsibility to bring about action, which seeks to transform society. This responsibility would call the church to move away from indifference, to walk out of its rim of fear and to confront the crises and challenges that face the society, with all the courage required. The church for reconstruction is useful and relevant for all, all the time.

4.Bishop Ishmael Mukuwanda is the bishop of the Anglican Diocese of Central Zimbabwe (Gweru). He is the current president of the Zimbabwe Council of Zimbabwe (Gweru). He is the current president of the Zimbabwe Council
Churches and the chairperson of Zimbabwe Heads of Christian Denominations. 


\section{The church for reconstruction embodies the spirit of the Bible}

The church for reconstruction should not only live on the axiom of the sayings of the Bible. Rather, it should possess the spirit of the Bible, for the Bible is a manual for daily living appreciated by all Christians (Chitando, Gunda \& Kugler 2013:10). What remains is to turn the text into practice and into possessing the 'spirit of the text - the Bible into practice' (Gunda 2013:21). If the spirit of the Bible is awakened within communities and churches, then the transformation of society is possible. The church for reconstruction embodies the Nehemiah biblical burning flames, the spirit of determination, the flame of commitment and the flame of hope. Reconstruction is possible when the church and believers possess the spirit of anger against suffering, and are then empowered with flames of determination to transform the status quo of injustice and burning with the flame of unending hope for a better nation.

The understanding of the crisis, discerning of the situation at hand and the collective mobilisation of the community remains a cause of concern to the successes of transforming society. It remains uncontested that the people of Zimbabwe live in exhilarating, yet challenging times (Tofa 2012:45). The time is indeed a critical time, post-independence, hovering between the wish of what should be and the undeniable presence of the unbearable. Zimbabwe is experiencing political, economic, social, legal and moral crises of staggering proportions (Chitando 2013:iv). In these times, the church is called to be the champion of reconstruction and to disregard the opposition, persecution and insults placed on it. The opposition and persecution the church faces currently is different from the threat levelled against Nehemiah and the wall builders. Today, the church can be attacked as a corporation, as in the case of the Anglican Church in Harare (2007-2012), ${ }^{5}$ or as an individual silencing of those clerics who dare to challenge the status quo as exhibited in the case of the former Roman Catholic Archbishop, Bishop Pius Ncube. ${ }^{6}$ These persecution targets are real and they require a real church of integrity standing on the transformative mission and embodying the spirit and the flames of the Bible to be able to withstand these onslaughts.

This means that in reconstruction times, 'the church has to be church', protecting the freedom and values of the gospel and at the same time standing for the integrity of the people (Dreyer 2016:2). In his Church Dogmatic, Barth (1956:661) articulates that the church is 'being both an invisible (spiritual) and visible (reality), an event of the Holy Spirit

5.The Anglican Church Diocese of Harare and Manicaland in Zimbabwe was exposed to the political polarised landscape from 2007 to 20122007 to 2012. The forme Bishops Kunonga of Harare and Jakazi of Manicaland claimed individual ownership of the church. This forced the Province of Central Africa to call for disciplinary action against them. This action spilled over into the civil courts with Kunonga and Jakazi against them. This action spilled over into the civil courts with Kunonga and Jakazi receiving support from ZANU PF and the state security machineries police and army buildings. 6. Archbishop Pius Ncube became a strong critic of President Robert Mugabe from
2000 because of because of the fast track land reform and he was forced to resign 2000 because of because of the fast track land reform and he was forced to resign
from the office in 2007 when the political heat in Zimbabwe became unbearable for him. and a historical entity'. Therefore, Christ is never absent from the church, for the church exists because of the activities of God. The church has to be church regardless of the threats, persecution and alienation that it faces. The doors of the church and the place of worship should remain relevantly appealing regardless of the struggles, the crisis and the brokenness in the world. While this is so, the physical elements of the church should essentially be necessary in the demands of the times in Zimbabwe.

The church embodying the spirit of the Bible comes up to teach and to make disciples. The spirit of the great commission of Matthew 28:18-20 makes sense when looked at from the context of Zimbabwe and the issues of post-colonial times. As with Matthew 28, the church should teach its believing congregations, baptise them and make disciples as a mission paradigm in Zimbabwe. During an interview on 07 January 2015, Paul Gwese explains that, to the Christian members or parishioners:

'the church should teach, and educate them the gospel which empowers them to live and exercise real discipleship. This discipleship has to embody the elements of stewardship and accountability which is really problematic in post-colonial Zimbabwe.' (Interview on 07 January 2015, Marondera)

This understanding affirms what David Bosch (1991) articulates:

In Matthew, preaching and proclaiming always refers to a message addressed to outsiders; it is frequently used together with the gospel of the kingdom. Jesus never preaches to his disciples; he teaches them. Similarly, in the synagogues and in the temple (among believers), Jesus always teaches. (p. 66)

In teaching the gospel, the church should make Jesus Christ real and relevant in the context of the believing community, but also make Jesus Christ and the kingdom of God's principles the content of the whole nation. The church embodying the spirit of the Bible will then proclaim and preach the love of one's neighbour which is the litmus test for the love of God. This preaching will challenge all sectors to reflect on their active commitment and deeds towards the welfare of the neighbour.

\section{The church: Community empowered for reconstruction}

Avery Dulles (1987:27; 1988) has achieved notability in providing a helpful and easily comprehensible system of models to help understand the church, the church's purpose and mission. Dulles (1987:48) has characterised models as 'realities having a sufficient functional correspondence with the object under study so that they provide conceptual tools and vocabulary'. Dulles proposed the following models of the church: the church as an institution, as a mystical body of Christ, as a sacrament, as a herald, as a servant and as a community of disciples. These types portray the relationship between the church and mission (Bosch 1991; Dulles 1987:56; 1988). The church in this article includes Christian individuals who are critically empowered by the spirit of the Bible to be 
the salt of the earth and the light of the world in the socioeconomic and socio-political struggles of the communities where they operate.

\section{The reconstruction church is a:}

kingdom community of people who reinforce one another in their commitment to the gospel and consciously seek to live out the qualities of the kingdom of God; equality, participation, fellowship and communion or in the words of Roman 14:17, justice, peace and joy. (Fuellenbach 2002:174-175)

This church is spiritual and also physical in outlook. Thus, the church is an inclusive mutual and moral community, never functioning as a fearful body guard, of the divine message, but always functioning as the one who brings good tidings of hope to the hopeless. In this case, the church must be understood in relation to the world and has a concrete role to play in the socio-political and socio-economic liberation of society. Barney Pityana's (1995) observation and conclusion of the model of the church in South Africa are relevant to the church in Zimbabwe. Pityana (1995) says:

The church is the community whose existence we already anticipate and which could be the example of human living. A relevant church today should be one without walls, which looks out to the world. It has to be an inclusive community. The challenge of the church should be continuous experimenting and living these different expressions of community. The church should be a sign of the kingdom of God. (p. 99)

The communal sacramental value of the church is to reveal the coming together of the people in searching for solutions of their many challenges rather than blaming one another. This sign and instrument of coming together for reconstruction is a missional drive, as the church exhibits the kingdom of God. This is perhaps most articulated in Barney Pityana's (1995) analysis of the 'church of integrity':

The time has come for churches to draw common (ecumenical) spirituality expressed in the songs and dances of the struggle periods in order to avoid narrow denominationalism, the role of lay leadership in politics, economics and social entities, the need for a more assertive cultural expression in congregational and a recognition of the role of women. (p. 90)

The ecumenical movement should then draw the church to address the relevant theological training for of theologians, priests and laity. For it is through the empowerment of church believers that social integrity is achieved in missional perspectives.

Furthermore, when genuine ecumenism defines the church, society is not confused by the descending mission voices and activities. This way the church becomes strong and bold in its mission, realistic in its propaganda de tat and conscious to its prophetic accountability. Genuine ecumenism will enable the church to engage and confront the powers that be, empowered to speak truth to power in love. In this light, the church becomes strong in its mission outlook, its propaganda de tat and its prophetic engagement, its confrontation with the powers that be in its consciousness of the state mission.
Genuine ecumenism protects the church from victimisation, unwarranted criticism, alienation and persecution.

\section{Church as a living movement for reconstruction}

The post-colonial church is to position itself as a living organisation. This is to say that church is a living organism in the sense of a cosmological understanding of living systems and organisms. A living organism approach seeks to structure the common life of a church around the rhythms and structures that mirror the community's experiences. As in a biological system:

there is a phenomenon known as the strange attractor, essentials that force, analogous to a compass or an animal's deep instinct which provides organisms with the impetus to migrate out of their comfort zone. (Capra 2002:124; Pascale, Millemann \& Gioja 2000:69)

These strange attractors are critical for the church as they reflect on its mission in the struggle facing post-colonial Zimbabwe. The church has to move out of its comfort zone to influence other social forces in transforming society.

There are four critical components in the metaphor of the living organism that can aid the church to be alive and remain integral in the challenges facing Zimbabwe (Hirsch 2006:182):

- All living things are intelligent; this innate intelligence creates strategies to survive and remain alive for the sustenance of the complex whole. It is critical to realise that the church has many intelligent believers.

- The life of the organism is profoundly interconnected; the primary operative idea is of relationships arranged in a dynamic network. The living systems theory recognises that belonging and being part of the larger system is critical for survival.

- Information brings change; living systems thrive on responding to information.

- It is important to adapt to the demands of the challenges; living systems have to constantly interact with the surrounding environment.

The church should use its professional Christians in influencing transformation. It is alive when as an organisation, it reaches out to many people. In so doing, there is a communion aspect that is sustained by the presence of the Holy Spirit, expressed in a network of interpersonal relationships of mutual concern and discernment.

Significantly, the church can be defined:

as a 'Jesus Movement' this label influenced the Apostles as narrated in the book of Acts to spread out the good news of Jesus and in mission to affirm wholeness in society. (Ramachandra 2006:51)

The movement in which deeds of power compel transformations are real and an invitation to communal commitment to justice and compassion is the basic rule of 
conduct, which must be demanded from society at large as well as from the church (Fuellenbach 1995:250-251; 2002:197). The Jesus movement invites all to repentance and conversion, while announcing the forgiveness of sin and encouraging all to become living members of Christ's earthly community while exhibiting a life of service to others. This makes the church a critical institution mandated to influence and participate in social reconstruction. For the Jesus movement is to perpetuate the Jesus gospel that is transformatively directed as demonstrated by Jesus himself (Lk 4:18) (Ramachandra 2006).

\section{Mission integrity and equipping the saint}

The church for mission is influenced by the integrity of Christian life, which is a life filled and transformed for the wholeness of society. The Zimbabwean context presents a challenge to the church to redefine theological training and theological reflections. Ezra Chitando speaks 'of a "deep crisis," an "immense crisis" that "deep social crisis" and urges theological educators and pastors that it must be "no more business as usual"' (Chitando 2013:iv; Chitando, Taringa \& Mapuranga 2014:174). Equipping priests, pastors and bishops with relevant reconstruction material has become more conversant with the contextual shape of suffering, struggle and crisis in post-colonial Zimbabwe. The contextual relevance in Zimbabwe should define the training of pastors and lay leaders of the church, so that they will be able to effectively equip the saints. The issues at the top of Zimbabwe's society should occupy the curricula of theological institutions and the church's proclamation of the gospel. Charles Villa-Vicencio (1992:40) argues that a theology that fails to address the realities faced by (ordinary) people is a false theology. The political and economic crisis in Zimbabwe has become an authentic engagement with the African cry (Ela 2005:28). Desmond Tutu has argued that there has been a trend where Christians in non-Western contexts have found that they 'possess answers and splendid answers at that, but answers to questions that nobody in their home contexts were asking or apt to ask' (Tutu 1983:107). Theological reflections in Zimbabwe cannot afford to ignore the existential realities that are characterised by political instability, corruption, unemployment, economic problems, social decadence, death and hopelessness (Chitando 2008:8).

How can theological reflection and education in Africa be conducted in a business-as-usual manner when thousands and millions of Africans are dying of civil war, hunger, unemployment and AIDS? (Maluleke 2003:63). This question highlights the relevance of doing mission in context, and being a church in post-colonial Zimbabwe. The church in mission for reconstruction is to equip the saints in training in matters of democracy and sovereignty, the case for the church and state relationships in the post-colonial Zimbabwe. In Zimbabwe, there is a culture of holding people at ransom for individual gain and benefit. This has been formalised by the political elders through denying people their democratic rights (Mlambo, Vambe \& Zegeye 2010:83; Ndlovu-Gatsheni 2009:1139).

The church has to prepare its members by training them for social mission, resource mobilisation, social transformation and community development. The church can exercise this ethical task or prophetic vision from different levels, ranging from influencing ethos, cultural values and the spirit of the times, through educating members on particular topics affecting people such as economic position and proposals, environmental concerns, political injustices and lobbying (Verstraelen 1998:48). The church is not a political opposition party that thrives by gaining power and political influence. The church is an answering team player that must be ready to assist the government in reconstructive and developmental ways.

\section{Conclusion}

The church that stands on integrity of mission addresses the challenges the community encounters. As virtue is learned through practice, the virtues of solidarity, communal wellbeing, universal love and genuine respect require the church to start reinvigorating in post-colonial times. The challenge is to find ways to cultivate those virtues and to develop a genuine sense of the common good. The article argues that the church is missionary and that the missio Dei empowers the church to be the conscience of society, prophetic, the embodiment of the spirit of the Bible and the living organism for transformation in Zimbabwe.

Reconstruction mission is founded on experience, theology and scripture. This article affirms that the church should champion the virtue of transformation. The church is invited to be a church with others, for others. It should be the embodiment of unity of purpose in the politically divided landscape of Zimbabwe. The church should mobilise Christian adherents to uphold genuine brotherhood or sisterhood and neighbourly solidarity in the context of transformation and reconstruction.

The objective of this article was to argue for a reconstruction vision for Zimbabwe, which should then be enacted by the prophetic engagement of all institutions because reconstruction is inclusive. The challenge of the prophetic church is how to engage political authorities without being persecuted, criticised and/or co-opted into becoming the political commissars. There is a need for sustainable development and collaboration in church-related training and research. The church needs to enhance its capacity to do research on national issues and to participate in policy development.

Prophetic engagement will be strengthened when churches give more attention to developing clergy and lay leaders in contextual social theology. If churches (established or not) are not more intentional about guaranteeing that training includes systematic social analysis and national policy, they 
will not be able to make serious contributions to policies affecting people. There is a particular national need at the moment for knowledge and expertise suited in the reconstruction call.

\section{Acknowledgements Competing interests}

The authors declare that they have no financial or personal relationships which may have inappropriately influenced them in writing this article.

\section{Authors' contribution}

C.B.S. and S.T.K. equally contributed to the research and writing of this article.

\section{References}

Bakare, S., 2013, Broken promise: A letter to my children, Weaver Press, Harare.

Balia, D. \& Kim, K., 2010, Witnessing to Christ Today: Volume 2 Edinburgh 2010 Regnum Books International, Oxford.

Banana, C.S., 1980, The Gospel according to the Ghetto, Mambo Press, Gweru.

Banana, C.S., 1991, Come and share: An introduction to Christian theology, Mambo Press, Gweru.

Barth, K., 1956, Church dogmatics, Revised edition, T\&T Clark, Edinburgh.

Bethge, E., 1972, Dietrich Bonhoeffer's letters and papers from prison, The Macmillan Company, New York.

Bishau, D., 2013, 'The prosperity Gospel: An investigation into its pros and cons with examples drawn from Zimbabwe', International Open and Distance Learning Journal, 1, (1), 65-76.

Bonhoeffer, D., 1967, Letters and papers from prison, The Macmillan Company, New York.

Bonhoeffer, D., 1974, Letters and papers from prison, The Macmillan Company, New York.

Bosch, D.J., 1991, Transforming mission: Paradigm shifts in theology of mission, Orbis Books, Maryknoll, New York.

Capra, F., 2002, The hidden connections: A science for sustainable living, HarperCollins, London.

Chimhanda, F., 2009, 'Church involvement in the transition to democracy in postcolonial Zimbabwe (1980-2008)', Studia Historiae Ecclesiasticae, 35, (1), 103-118.

Chipenda, J.B., 1997, 'Being the church in Africa' in J.N.K. Mugambi, (ed.), The church and reconstruction of Africa: Theological considerations, pp. 26-38, All African Conference of Churches, Nairobi.

Chitando, E., 2008, 'Theological education in the heat of battle: Mainstreaming HIV and AIDS', in E. Chitando, (ed.), Mainstreaming HIV and AIDS in theological education: Experience and explorations, pp. 6-18, World Council of Churches, Geneva.

Chitando, E., 2009, Troubled but not destroyed: African theology in dialogue with HIV and AIDS, World Council of Churches Publisher, Geneva.

Chitando, E., 2013, 'Introduction: Prayers and players: Religion and politics in troubled times in Zimbabwe' in E. Chitando, (ed.), Prayers and players: Religion and politics in Zimbabwe, pp. vi-xv, Sapes Books, Harare.

Chitando, E., Gunda, M.R. \& Kugler, J., 2013, 'Introduction: Back to the future! A reader on the bible, prophets and profits in Zimbabwe' in E. Chitando, M.R. Gunda \& J. Kugler, (eds.), Prophets, profits and the bible in Zimbabwe, pp. 9-4, University of Bamberg Press, Bamberg,

Chitando, E., Taringa, N.T. \& Mapuranga, T.P., 2014, 'Zimbabwean theology and religious studies during the crisis years (2000-2008): A preliminary study', Studia Historiae Ecclessiasticae, 40 (1), 173-189.

Coula, C.B., 1997, 'Fostering peace for genuine and sustainable development', in J.N.K Mugambi, (ed.), The church and reconstruction of Africa: Theological considerations, 211-221, All African Conference of Churches, Nairobi.

Dedji, V., 2001, 'The ethical redemption of African imaginaire: Ka Mana's theology of reconstruction' Journal of Religion in Africa, 31(3), 254-274, https://doi. org/10.2307/1581609

De Gruchy, J., 2002, Reconciliation: Restoring justice, SCM Press, London.

Dowling, K., 2016, 'Bishops as theologians: Listening, discerning and dialogue' in A.E. Orobator, (ed.), The church we want: African Catholics look to Vatican III, pp. 3-10, Orbis Books, Maryknoll, New York.

Dreyer, W., 2016, 'Church, mission and ethics: Being church with integrity' HTS Teologies Studies/Theological Studies, 72 (1), 1-9, viewed 23 January 2017, from http://www.hts.org.za/index/php/HTS/article/view/3163/htm

Dulles, A., 1987, Models of the church, Expanded edition, Image Books, New York.
Dulles, A., 1988, Models of the church, Gill and Macmillan, Dublin.

Ela, J.M., 2005, Africa cry, Wipf and Stock Publishers, Eugene, Orgen.

Engen, C.V., 2006, 'Towards a missiology of transformation', in C.V. Matthew, (ed.), Integral mission: The way forward, pp. 74-105, C.S.S Christava Sahitya Samithi, Tiruvalla.

Flemming, D., 2005, Contextualisation in the New Testament: Patterns of theology and mission, InterVarsity Press, Downers Grove, Illinois.

Fuellenbach, J., 1995, The Kingdom of God: The message of Jesus for Today, Orbis Books, Maryknoll, New York.

Fuellenbach, J., 2002, The meaning of the church in the teaching of Vatican II: The use of models in ecclesiology, Orbis Books, Maryknoll, New York.

Gathogo, J.M., 2007, 'A survey on an African theology of reconstruction', Swedish Missiological Themes, 95 (2), 19-44.

Gunda, M.R., 2013, From text to practice: The role of the Bible in daily living of African people today, Univeristy of Bamberg Press, Bamberg.

Heaney, R., 2015, From historical to critical post-colonial theology: The contribution of John S Mbiti and Jesse N.K. Mugambi, Pickwick Publications, Eugene, Oregon.

Hiebert, P.G., 2006, 'Are we our others' keeper? Western Images of others and otherness' in in C.V. Matthew, (ed.), Integral mission: The way forward, C.S.S Christava Sahitya Samithi, Tiruvalla, 196-220.

Hill, G., 2005, What happens after Mugabe, Zebra Press, Cape Town.

Hirsch, A., 2006, The forgotten ways: Reactivating the missional church, Brazos Press, Grand Rapids, Michigan.

Hunter, R.J., 1990, Dictionary of pastoral care and counselling, Abingdon Press, Nashville, TN.

Hoedemaker, \& M.R. Spindler, (ed.), Missiology: An ecumenical introduction, pp. 123-143, Williams B Eerdmans Publishing Company, Grand Rapids, MI.

Ilo, S.C., 2016, 'The church of Pope Francis: An ecclesiology of accountability, accompaniment and action', in A.E. Orobator, The church we want: African Catholics look to Vatican III, pp. 11-30, Orbis Books, Maryknoll, New York.

Jenkins, O.B., 1984, Missions: A modern definition, Communication Press; Baptist Publications, Nairobi.

Kirk, J.A., 1999, What is mission: Theological exploration, Longmann and Todd Darton.

Lamont, D.R. 1959, Purchased people (1 Peter 2:9): A pastoral letter to the faithful of the diocese of Umtali, Catholic Archives Mutare, Mutare.

Macquarrie, J. 1977, Principles of Christian theology, 2nd edition, Charles Scribner, New York.

Maluleke, T.S., 2003, 'Towards and HIV/AIDS sensitive curriculum' in M.W. Dube (ed.), HIV/AIDS and the curriculum: Methods of integrating HIV/AIDS in theological programmes, pp. 60-78, World Council of Churches, Geneva.

Mana, K. 1991, Afrique va-t-elle Mourir (Will Africa Die), Cerf., Paris.

Maposa, R.S., Sibanda, F. \& Makahamadze, T., 2011, 'African theology and identity Reflections on Zion Christian Church experiences and responses to the Zimbabwean crisis, 2000-2010', Missionalia: Southern African Journal of Missiology 39 (3), 248-267.

Mayemba, B., 2016, 'Reviving a church of the poor and for the poor and reclaiming faith doing justice and seeking liberation: Convergence between Pope Francis and Jean Marc Ela' in A.E. Orobator, (ed.), The Church we want: African Catholics look to Vatican III, pp. 67-82, Orbis Books, Maryknoll, New York.

Mlambo, A., Vambe, M.T. \& Zegeye, A., 2010 'The culture of crisis of culture in Zimbabwe', African Identities, 8 (2), 79-91, https://doi.org/10.1080/1472584 1003785112

Moltmann, J., 1977, The church in the power of the spirit: A contribution to messianic ecclesiology, SCM Press, London.

Motte, M., 1992, 'Conversion: A missiological perspective', The Ecumenical Review, 44 (4), 453-457.

Mugambi, J.N.K., 1989, African Christian theology: An introduction, Heinemann, Nairobi.

Mugambi, J.N.K., 1995, From liberation to reconstruction: African Christian theology after the cold war, East African Educational Publishes, Nairobi.

Mwaura, P.N., 2010, 'Mission as service of justice, peace in the church in Africa' in J. Raja, V. Ogden, G. Wauchope \& S. Fernando, (eds.), Towards a reconstruction of mission stories, pp. 3-22, ISPCK, Delhi.

Ndlovu-Gatsheni, S.J., 2009, The decolonial Mandela: Embodiment of peace, justice and humanism, viewed 15 October 2015, from http://www.tandfonline.con/loi/ ctwq20

Nel, M., 2010, Missional integrity and contextual relevance', HTS Theological Studies, 67 (3), 88-97.

Pascale, R.T., Millemann, M. \&Gioja, L., 2000, Surfing the edge of chaos: The laws of nature and the new laws of business, Three Rivers Press, New York.

Phiri, I.A., \& Nadar, S., 2010, 'African women's theologies', in D. Stinton, (ed.), African theology on the way: Current conversations, pp. 90-100, SPCK, London.

Pityana, B., 1995, 'Culture and the church: The Quest of a new ecclessiology', in B. Pityana, \& C. Villa-Vicencio, (eds.), Being the church in South Africa today, pp. 87-99, South African Council of Churches, Johannesburg.

Pobee, J., 1990, 'Lord creator spirit, renew and sustain the whole creation: Some missiological perspectives' International Review of Mission, 79, 151-158, http:// doi.org/10.1111/j.1758-6631.1990.tb02182.x 
Poggo, A., 2013, Come let us rebuild: Lessons from Nehemiah, Millipede Books, Hertford.

Rahner, K., 1974, The shapes of the church to come, The Seabury Press, New York.

Raja, J., \& Benjamin, S., 2010, Media and mission: Understanding Christion mission in the new emerging public space, ISPCK, Dehli.

Ramachandra, V., 2006, 'Integral mission: Exploring a concept', in C.V. Matthew, (ed.) Integral mission: The way forward, pp. 44-59, Christava Sahitya Samithi, Tiruvalla.

Roget's International Thesaurus, 2010, Integrity: Meaning, 7th ed., Harper Collins Publication, London.

Rzepkowski, H., 1974, 'The theology of mission', Verbum SVD, 15, 79-91.

Samuel, S., 1998, The spirit pathos and liberation: Toward a Hispanic Pentecostal theology, Sheffield Academic Press, Sheffield.

Spindler, M.R., 1995, 'The biblical grounding and orientation of mission', in A. Camps, L.A. Hoedemaker \& M.R. Spindler (ed.), Missiology: An ecumenical introduction, Williams B Eerdmans Publishing Company, Grand Rapids, MI.

Tamez, E., 2001, 'An ecumenical community: Women's vision and voices', The Ecumenical Review, 53 (1), 57-63, https://doi.org/10.1111/j.1758-6623.2001. tb000073.x
Temples, W., 1942, Christianity and social order, Lambeth Publication, London.

Tofa, E., 2012, 'The Bible and the quest for democracy and democratisation of Africa: The Zimbabwean experience', in M.R. Gunda, \& J. Kugler, (eds.), The Bible and politics in Africa, pp 42-60, University of Bamberg Press, Bamberg.

Togerasei, L., 2008, 'Fighting HIV and AIDS with the Bible: Towards HIV and AIDS biblical criticism', in E. Chitando, (ed.), Mainstreaming HIV and AIDS in theological education: Experiences and explorations, pp. 71-84, World Council of Churches Publishing, Geneva.

Tutu, D., 1983, Hope and suffering: Sermons and speeches, Skotaville Publication, Johannesburg.

Verkuyl, J., 1978, Contemporary missiology: An introduction, William B Eerdmans Publishing Company, Grand Rapids, MI.

Verstraelen, F.J., 1998, Zimbabwean realities and Christian responses: Contemporary aspects of Christianity in Zimbabwe, Mambo Press, Gweru.

Villa-Vicencio, C., 1992, A theology of reconstruction: Nation building and human rights, Cambridge University Press, Cambridge.

Wright, C.J.H., 2006, The mission of God: Unlocking the Bible's narrative, InterVarsity Press, Downers Grove, IL. 